\title{
Glomerular and Tubular Functions in Transfusion-Dependent Thalassemia
}

\author{
Transfüzyona Bağımlı Talasemide Glomerüler ve Tübüler Fonksiyonlar
}

(D) Pathum Sookaromdee ${ }^{1}$, (D) Viroj Wiwanitkit ${ }^{2}$

${ }^{1}$ TWS Primary Care Center, Bangkok, Thailand

${ }^{2}$ Hainan Medical University, Department of Tropical Medicine, Haikou, Hainan, China

To the Editor,

Annayev et al. [1] reported their interesting observations in the publication entitled "Glomerular and Tubular Functions in Children and Adults with Transfusion-Dependent Thalassemia" (TDT). They concluded that "subclinical renal injury may be present in TDT patients" [1]. We would like to share ideas and experiences from our setting in Southeast Asia where transfusion-dependent beta-thalassemia is very common. Renal dysfunction is not uncommon in our thalassemic patients and the degree of dysfunction varies [2]. In fact, the varying degree of renal dysfunction in thalassemia patients is well known $[3,4]$. Patients with different variants of thalassemia have different degrees of renal dysfunction $[3,4,5]$. Ong-ajyooth et al. [5] noted that "The mechanism leading to the damage is not known but it might be related to increased oxidative stress secondary to tissue deposition of iron, as indicated by the raised levels of serum and urine MDA". Improved renal function is also observed after stem cell transplantation therapy [6].

Keywords: Glomerular, Tubular, Thalassemia

Anahtar Sözcükler: Glomerüler, Tübüler, Talasemi
Conflict of Interest: The authors of this paper have no conflicts of interest, including specific financial interests, relationships, and/or affiliations relevant to the subject matter or materials included.

\section{References}

1. Annayev A, Karakaş Z, Karaman S, Yalçıner A, Yılmaz A, Emre S. Glomerular and tubular functions in children and adults with transfusion-dependent thalassemia. Turk J Hematol 2018;35:66-70.

2. Sumboonnanonda $A_{1}$ Malasit $P$, Tanphaichitr VS, Ong-ajyooth $S_{\text {, }}$ Sunthornchart S, Pattanakitsakul S, Petrarat S, Assateerawatt A, Vongjirad A. Renal tubular function in beta-thalassemia. Pediatr Nephrol 1998;12:280283.

3. Nickavar A, Qmarsi A, Ansari S, Zarei E. Kidney function in patients with different variants of beta-thalassemia. Iran J Kidney Dis 2017;11:132-137.

4. Uzun E, Balcı YI, Yüksel S, Aral YZ, Aybek H, Akdağ B. Glomerular and tubular functions in children with different forms of beta thalassemia. Ren Fail 2015;37:1414-1418.

5. Ong-ajyooth L, Malasit P, Ong-ajyooth S, Fucharoen S, Pootrakul P, Vasuvattakul S, Siritanaratkul N, Nilwarangkur S. Renal function in adult beta-thalassemia/Hb E disease. Nephron 1998;78:156-161.

6. Sumboonnanonda A, Sanpakit K, Piyaphanee N. Renal tubule function in beta-thalassemia after hematopoietic stem cell transplantation. Pediatr Nephrol 2009;24:183-187. 


\section{Reply to the Authors:}

To the Editor,

We thank Drs. Sookaromdee and Wiwanitkit for their interest and contribution to our article. There is a growing evidence of renal dysfunction in patients with thalassemia. Although the process is multifactorial (the disease itself with regular transfusion, iron accumulation in the parenchyma and toxicity of chelators), oxidative stress seems to be the main mechanism of renal damage. Several studies have shown the beneficial effects of antioxidants (curcumin, glutamine) in prevention of chemotherapy-induced nephrotoxicity by decreasing oxidative damage. Considering the significantly increased life expectancy of thalassemia patients with long-term complications, we think the role and effects of antioxidant treatments in routine follow-up of the thalassemia patients should be investigated in prospective studies.

Best Regards

Zeynep Karakaş, Serap Karaman

\section{Use of Plerixafor to Mobilize a Healthy Donor Infected with Influenza A}

Influenza A ile Enfekte Olan Sağlıklı Bir Vericinin Plerixafor ile Mobilizasyonu

(D) Mahmut Yeral, (D) Pelin Aytan, (D) Can Boğa

Başkent University Adana Practice and Research Center, Adult Bone Marrow Transplantation Center, Adana, Turkey

To the Editor,

The combined use of plerixafor and granulocyte-colony stimulating factor (G-CSF) improves mobilization in poor mobilizers. However, there are limited data available on the use of plerixafor in healthy donors $[1,2]$. The effects of influenza $A$ infection on stem cell mobilization are not known.

A 46-year-old male was selected as an HLA-matched donor for a patient diagnosed with acute myeloid leukemia (AML). Donor assessment was performed in accordance with the standard operating procedure prepared for JACIE (SOP: BMT-CU-006, Donor Assessment and Safety). The donor was given $10 \mathrm{mg} / \mathrm{kg} /$ day G-CSF. He developed a dry persistent cough, chills, fever of $39{ }^{\circ} \mathrm{C}$, fatigue, and flu-like symptoms on day 3 of G-CSF administration. The donor was considered to have an upper respiratory tract infection, which could not be attributed to only G-CSF administration. The family members of the donor were found to have similar symptoms. Thus, blood and urine cultures were obtained and he was started on levofloxacin in addition to paracetamol; G-CSF was continued. A respiratory tract virus panel was performed on a nasal smear using a PCRbased technique. The peripheral blood leukocyte count was $22,000 / \mu \mathrm{L}$ but CD34+ cells represented just $0.07 \%$ of all cells $(11 / \mu \mathrm{L})$ on day 5 of G-CSF administration; this was considered to reflect "poor mobilization". Therefore, $0.24 \mathrm{mg} / \mathrm{kg}$ plerixafor was administered "just in time," in addition to G-CSF, on night 5 , after the donor had been given all necessary information and informed consent had been obtained. Two hours after the $11^{\text {th }}$ dose of G-CSF, the leukocyte count was $45,000 / \mu \mathrm{L}$, of which $0.33 \%(148 / \mu \mathrm{L})$ were CD34+ cells. Peripheral stem cell apheresis was performed using the Donor Spectra Optia Apheresis System (Terumo BCT, Lakewood, CO, USA). A total of $15.20 \times 10^{8}$ nuclear cells $/ \mathrm{kg}$ were collected. The product contained $3.92 \times 10^{6} \mathrm{CD} 34+$ cells $/ \mathrm{kg}, 14.91 \times 10^{7} \mathrm{CD} 3+$ cells $/ \mathrm{kg}, 17.36 \times 10^{7} \mathrm{CD} 19+$ cells $/ \mathrm{kg}$, and $7.17 \times 10^{7}$ CD56+ cells $/ \mathrm{kg}$. G-CSF was discontinued after an adequate number of stem cells had been collected, but the fever persisted. Oseltamivir at $150 \mathrm{mg}$ twice daily was then prescribed for the donor because the respiratory tract virus panel examination revealed influenza $A$ infection. The fever became controlled $24 \mathrm{~h}$ after oseltamivir administration. The plerixafor procedure was considered to have permitted "sufficient mobilization" in a healthy donor who could not be mobilized with G-CSF probably because of his influenza infection.

Many factors including age, sex, body mass index, baseline leukocyte count, and comorbid conditions may compromise mobilization [3]. Although certain viral infections may cause poor mobilization, data on the influence of influenza in this context are rather limited [4]. Cytokine production or cytokine storm developing during influenza infection may be presumed to impair stem cell mobilization [5]. A combination of G-CSF and 